\title{
Individuals and International Public Opinion as an Actor in International Relations
}

\author{
Utangisila Bena Osée, Bijimine Tshipamba Bijoux, Shafiko Biasuba Didier, \\ Elembe Oyangondo François
}

Central China Normal University, Wuhan, China

Email: oseebena@yahoo.com

How to cite this paper: Osée, U.B., Bijoux, B.T., Didier, S.B. and François, E.O. (2019) Individuals and International Public Opinion as an Actor in International Relations. Open Journal of Social Sciences, 7, 478-490. https://doi.org/10.4236/jss.2019.73039

Received: February 19, 2019

Accepted: March 26, 2019

Published: March 29, 2019

Copyright () 2019 by author(s) and Scientific Research Publishing Inc. This work is licensed under the Creative Commons Attribution International License (CC BY 4.0).

http://creativecommons.org/licenses/by/4.0/

\section{(c) (i) Open Access}

\begin{abstract}
The term "International public opinion" is now also used by various actors outside the militant field. The media but also governments and international organizations that invoke international public opinion tend to make it a uniform and sometimes lively entity: public opinion can thus "be moved"; "indignant" and even undergo "psychological shocks". Individuals are of crucial importance to world affairs, this idea is based on certain assumptions such as, acquisitions of better analytical skills, global political system has entered a period of prolonged turbulence which makes it particularly sensitive to micro politics influences and the upheaval of skills is considerable since citizens today shape the overall results in a much more important way than in the past.
\end{abstract}

\section{Keywords}

Individuals, International Public Opinion, International Relations, Actor

\section{Introduction}

The terms "public opinion" are part of the familiar vocabulary, political culture of our modern democratic societies [1]. Often evoked, public opinion seems to be at the heart of the concerns of the main players in these democracies: the intensive use of polls by politicians (Carrier 2006; White 2005; Jacobs and Shapiro 1995), and by the media (Pétry and Bastien 2009; Nadeau et al. 2008; Rosenstiel 2005; Patterson 2005) [2]. It is also the focus of many researchers interested in democratic theory and practice. However, despite its current dominant character, this conception of public opinion is not without raising important questions [3].

In addition to the methodological limitations of the survey, the limits of public opinion thus considered create a certain discomfort. That being said, the 
meaning that is being lent to the notion of public opinion is not self-evident [4]. It has evolved a lot over time. Various conceptions of public opinion have periodically imposed themselves throughout history, occupying for a time the top of the pavement. These designs varied according to the epochs, backgrounds, cultures and measuring tools available, as was raised by Habermas (1989) and Herbst (1993; 1998), among others [5]. The concept of public opinion is now abundantly used in the common political vocabulary and even before the word appears and its use becomes so widespread, many philosophers and theorists in all Genres have reflected on the phenomenon that the term public opinion means today [6]. We can find in Plato and Aristotle several passages dealing with what we refer to today as "public opinion" and the Prince of Machiavelli can be read as an attempt to provide the prince with techniques to manage the power derived from the voice of the people.

The concern for what we now call public opinion is far from being recent, and in addition to the three authors named above, it is also found at Hobbes, Locke, Rousseau, Tocqueville, Bryce and many others. That concern for public opinion, conceived summarily as the political opinions of the general population, the "voice of the people" being one of the fundamental elements of democracy. This being so, the meaning attributed to the concept of public opinion remains ambiguous today and has varied over time. Recognized as heirs of a traditional tradition hitherto limited to the analysis of international relations, the theories of international relations must now develop new paradigms integrating individuals who now hold a decisive place in the international scene.

More specifically, it is a matter of understanding how changes in the conduct or aptitude of individuals are likely to lead to changes in the state government. We can only see that the knowledge is being used, or the international use of notoriety works to change the authority of States (Rosenau J., 1994). These phenomena reveal state actors increasingly challenged by individuals capable of aggregating their actions into collective action with sometimes major effects. For the time being, these weakly institutionalized movements and the multiple horizontal links represent the best guarantors of the effectiveness of individuals in the face of States [7]. This study focuses on the analysis of individuals and international public opinion as an actor in international relations. This article is structured as follows: 1) Definition of the concept of public opinion; 2) Individuals as actors in international relations; 3) Main functions of public opinion; 4) Theoretical value for the study of public opinion; 5) Practical and theoretical importance of the research; 6) Discussion; 7) Delimitation of research; and finally conclusion.

\section{Definition of the Concept Public Opinion}

For a long time public opinion was perceived as irresponsible, changing, ill-informed and emotional, and public opinion was deemed unfit to participate in the management of public affairs and foreign policy. It was only from the 
years 1950, under the influence of some currents in American political sociology, that public opinion has been gradually identified and sometimes legitimized as a factor entering the process of political decision making.

Public opinion is called the judgment of citizens on a topical issue (political, economic, social, etc.). In order to know public opinion, surveys are organized, a technique that involves interrogating a part of the population to find out the opinion of the whole population. But the results of a poll have no legitimacy, because the popular will can only be expressed by the vote. The vote is, in the end, the expression of the choice of the citizens on the great debates of the community. The media are an essential means of expressing the diversity of viewpoints, which allow everyone to form their opinion.

Public opinion can be defined as a set of beliefs and values more or less shared by the population of a given society at a given time. In a democracy, public opinion becomes a political issue: it is its conquest and control that depends on the fate of the ballot boxes and the exercise of power. One can try to measure it by the use of the polls, even if these are not its complete and complex reflection. Public opinion is being fashioned at two points in the political life of a nation: in the elections and in the political crisis.

At the outset, public opinion referred to the enlightened opinion of elite. This concept was then progressively democratized to encompass the opinion of all citizens today. The polls, which offer a photograph of public opinion, have become the reference tool for measuring it. But this measure is not free from criticism. Some, like Pierre Bourdieu, underline his illusory aspect and denounce his instrumentalization for political purposes (public opinion, he says, does not exist) [8]. Others like Bernard Lacroix see them as a police element in debates that would threaten democracy. In all cases, public opinion is the subject of a struggle for its definition: scientists, journalists and political actors continue to use it to justify their analyses or actions [9].

It should be noted that all the people who make up public opinion have seen a parallel enlargement to the extension of the vote. The term of public opinion appeared in the XVIIIe century, but its meaning was subsequently enriched, particularly under the influence of the French Revolution. Three semantic evolutions can be schematically drawn up: Public opinion in XVIIe century France: public expression of the personal opinions of the bourgeoisie then in full economic growth and which intends to influence the authorities Policies by making public various texts (pamphlets, brochures, libels, etc.). In solidarity with the current of Enlightenment, the latter wishes to use reason to criticize the arbitrary use of power and calls on the court of public opinion (implied by the enlightened opinion) to denounce judicial errors;

Public opinion during the Revolution of 1789: Opinion of members of the $\mathrm{Na}-$ tional Assembly and active citizens who express themselves in newspapers or clubs. It is always in line with the philosophy of enlightenment which makes the discussion and public debate a necessary precondition for the determination of the general wills, separate will of the sum of the individual wills because seeking 
to reach the common interest. It is also elitist, constructed and public (i.e. worthy of publication), and therefore opposes the opinion of the people judged then irrational and poorly educated, prone to prejudice.

Public opinion of the second half of the XIXe century: two major changes lead to an evolution of the notion, namely, on the one hand, the adoption of the male censual suffrage in 1848 which makes elected representatives of the people speaking on its behalf; On the other hand, the constitution of a workers' proletariat in cities that is organized within political organizations and that manifests on the street to obtain rights. Between these two parts of public opinion, there may be conflicts, each group claiming to embody the true opinion of the people. In addition, the development of a large-circulation press will lead some journalists to speak on behalf of public opinion, the sale of their newspapers meaning an implicit adherence of the reader to their political line. Of these three steps, it is possible to identify a guiding thread: Public opinion is always the result of the thoughtful activity of individuals who are politically involved http://www.le-politiste.com/lopinion-publique/.

\section{Individuals as Actors in International Relations}

Individuals, natural persons as actors in international Relations are a recent phenomenon not yet fully codified or widespread. But in general the sovereignty of States is limited in the face of the obligatory ones arising from international human rights law. The Charter of Human Rights (Universal Declaration of $\mathrm{Hu}$ man Rights of 1948) places the individual, his reason, and his interests at the center of history and politics (internal and international). Henceforth, human rights are part of the principles of the legal, economic, socio-cultural and international political order. The public actors (States and IGOs) of international relations are bound to respect and implement the various conventions on human rights. This obligation has provoked a new reading of the principle of "non-interference in the internal affairs of States" under human rights.

Obviously this new vision has aroused and still arouses political polemics provoke the interpretations of each other, human rights are nowadays one of the principles of the world political order by making the Individual a "Sui generis" subject of international law and thus an actor in international Relations. In the political system of Western Europe the individual has become practically an active player in European international relations (Cfr. European Court of Human Rights). In Postcolonial Africa, the Banjul Charter on the rights of peoples and men exists, but its effective implementation is still in the waiting room. Classical doctrine considers that individuals are not international actors because they are not subjects of international law. However, it is difficult to deny the importance of certain heads of state, who become historical figures and on which important decisions are ultimately weighed. Of course, history cannot be explained by the action of the "Great men". But the action of such or such a powerful ruler can mark the story in a negative way (Hitler, Stalin) or positively, that one thinks of Gandhi, Mandela, Gorbachev, Obama, etc. [10]. Moral or religious figures (the 
pope, the Dalai Lama) have also had an important international action that exceeds the only spiritual setting. The same goes for some big business owners. In the years 1990, George Soros, a Hungarian-born American, is a symbol of the strong role that some individuals can play on a global scale and becomes one of the physical incarnations of the "market" that would now guide the world [11].

Indeed, in 1992, the company he runs speculates against the pound sterling, helping to oblige the British government to devalue. By the way, he's pocketing a billion dollars' worth of capital. Here we have the elements of a new distribution of power based on the invisible rules of the market: a man and the financial company he runs have made the government of one of the world's most powerful countries cede! He will re-offend in 1997-1998, during the Asian crisis, and even be introduced by some leaders of the region as the public Enemy.

At the same time, it is undertaking large-scale sponsorship actions in Eastern Europe and Russia, in particular to support democracy. Again, the image is strong; the patronage of an individual can contribute more effectively than the action of the Great powers to shape the political system of the former members of the Warsaw Pact. Microsoft's boss, Bill Gates, considered the world's richest man, paid, for the year 2005 alone, 250 million to the World Health Organization (WHO). In addition, he created a foundation with a capital of 31 billion million, which was joined by billionaire Warren Buffett for 37 billion million, equivalent to the GNP of Vietnam or Slovakia at the time. Some billionaires, often those whose fortunes are recent, have weight towards governments. Some control media that reinforce their influence http://medias.dunod.com/document/9782200617080/P040-052_Comprendre-lemonde-Boniface.pdf.

There are no compilations of transnational relations made by individuals. Yet the latter are multiple and important. To be convinced of this, we can consult the statistics of the United Nations on migratory or tourist flows which have risen very significantly over the last thirty years. But these flows represent only a part of the individual transnational relations. It is also necessary to consider the cross-border economic and financial transactions carried out by citizens (purchase of shares, buildings, land, investments of sums of money in tax havens, etc.); the incomes that immigrants transfer to their families in their home countries, and those perceived by artists, professionals and scientists for their services abroad. Although the balances of payments of the different countries take account of these transactions, they do not distinguish them from those made by non-profit (SME, FMN) and nonprofit NGOs. However, some central banks account for the sums of money sent by immigrant workers to their country of origin. In 2009, these sums totaled US $\$ 42$ billion in the United States, 16.2 billion in Saudi Arabia and more than 6 billion in Switzerland. Diane Éthier, (2010), were income of 52 billion for India, 49 billion for China, 26 billion for Mexico, 19 billion for the Philippines, and between 7 and 9 billion for Poland, Nigeria, Romania, Bangladesh, Egypt and Vietnam [12]. The lack of a systematic and reliable assessment of individual transnational relations is certainly a problem, as 
the latter have a major impact on international society. But how to account for them, when they have taken on an unprecedented scale in the context of globalization and a multitude of them are virtual in nature, being concretized through the websites of government organizations and Non-governmental, e-mail, social networks like Facebook and Twitter, fax machines and traditional, cellular or satellite phones. However, the exponential multiplication of daily communications between millions of individuals in different countries is a new phenomenon, which in-depth changes transnational relations. It is important to wish that the specialists are more interested in the near future.

\section{International Public Opinion as an Actor in International Relations}

Public opinion as a fact is an assertion that means a position or affirmation that contains cognitive or rational elements and emotional elements. It is to be placed in the category of private actors of international relations. Individual opinion is not to be confused with public opinion. The opinion is called "public" when it aggregates a series of individual opinions and if it manages to constitute a collective current or movement that recognizes itself and translates into an identical assertion.

Public opinion is the result of the constellation of individual opinions. This is why public opinion is considered a "social fact". Public opinion is manifested in several ways:

* By the convergence of individual reactions on a given topic (example: Signatures affixed to a memorandum);

By Collective Demonstrations (example: mass demonstration by a march);

By election consultations;

* By survey results.

It should be noted that public opinion differs from other actors in international relations by its character of extreme complexity. In fact, the following common traits characterize public opinion as agents of international relations, namely:

$>$ It is a composite phenomenon i.e. it is divided into several tendencies on the same phenomenon (except in a country without freedom of opinion). But in some extreme cases such as war, there is generally a broad consensus around defending common values (the unity of the country).

Public opinion is not necessarily less coherent: this means that it can simultaneously admit positions that are objectively contradictory.

It governs the event and not precedes it: in this stage public opinion expresses feelings of fear, support, apprehension or hope caused by the occurrence of an event.

Public opinion is versatile: the versatility of public opinion is measured first by the variations in the intensity of the reactions. Opinion is able to demobilize as quickly as it has mobilized for a given cause. An example can be given 
in DR Congo for C.N.S and AFDL. Whereas the Constitution of DRCongo did not properly define the actual situation of the guarantor of the nation when the elections were not organized within the legal period in accordance with article 70 of the Constitution while the CNS of 1991 had given a glimmer of hope to this people, unfortunately this hope had flown away because it was with force that the CNS was closed; that since that time the population is always decrying the political crisis without finding a real way out. That it is in this momentum that the alliance of Democratic Forces for Liberation (AFDL) was created to provide an adequate solution, unfortunately some authorities, members of this alliance have turned away from the political line as defined In the AFDL agreements. In order to materialize one of the major objectives adopted in the said agreements to complete the work of the NSC, the Front of the national liberation of the Congo (FLNC) under the impetus of its Leader, Kapend Elie Kanyimbu, co-founder of AFDL, has sought and obtained from the government the reopening of the CNS as a forum bringing together all the lively forces of the nation in this case the emperors and customary leaders, the political parties (majority and opposition), civil society, executive Academics, personalities of public knowledge to find solution to the political crisis of the country.

However, trends in opinion seem to be stabilizing in depth or in the long term. We can say that the opinion makes mood swings sometimes astonishing but it also knows how to ensure the continuity of views or the adaptation of its views to the circumstances of time.

It is usually mobilized around topical topics. But if we exclude periods of crisis, public opinion focuses on domestic policy issues and it is only after it tackles international problems. Priorities often go to problems of unemployment, standard of living or inflation. The opinion on international problems is often improvised, without experience, without thorough reflection and without meaningful comparison, because often there is lack of information on distant facts.

Luhmann (2013), defines public opinion as "the environment, internal to the political system, organizations and political interactions" [13]. This must be understood since the thesis of the operational closure of any system, which implies that a system cannot cross its own borders. On the other hand, he can think of such a limitation by assuming that other systems are responsible for the irritations he suffers. The political system reflects the fact that it is observed from the outside; and public opinion is precisely the mirror that allows the political system to observe itself. Such a second-rate observation does not mean that something is being observed, but that observers are being observed.

The policy working for Luhmann, (2000, 2009), as a market, public opinion makes it possible to observe the reactions of the voters, the positioning of the competitors with regard to the themes proposed by the mass media [14]. But the political system does not only observe those that others observe; To the extent 
that it accesses public visibility, political communication must be shaped by taking into account the fact that it is being observed. In this way, public opinion ensures the operational closure of the political system and completes "the Autistic world of politics". It remains that this second-order observation involves a necessary blind spot and obscures the real complexity of the real: "Public opinion is not used to establish contacts with the outside world; it ensures the autoferential closure of the political system, allowing the latter to guide its operations.

\section{Main Functions of Public Opinion}

This point is focused on the main functions of public opinion. It is worth mentioning that public opinion plays several functions namely: informing, raising awareness, publicity, protest and demonstration.

\subsection{Awareness-Raising}

Public opinion uses the media because it makes it possible to raise public awareness on prevention issues. This is how topics such as public health and social issues are addressed. In order to better sensitize us the media use things that will touch, move us, hit us or even shock us. For this they use various methods: for the written press this can be a slogan marking with striking colors. For the radio it is enough to have a melodious music or on the contrary brutal. And finally, television, internet and advertising gather all this because they seek to touch our view, using music, colors and images that we will mark. The sensational photo is also regularly used by the media: it is about making close-ups on the tragic scenes, to insist on the contrasts of situation or scenery, to emphasize the unusual etc. The concept of Scoop is also widely used to sensitize: it is the principle of having a stolen information or photograph, which stirs up a person's curiosity.

\subsection{Inform}

Public opinion plays this role using social networks/media can prove to be effective in raising public awareness of climate change. It is a simple and skillful way of bringing people together and disseminating information. This allows everyone to give their opinion because, unlike the traditional media (television, radio, newspapers ...) that depend on the editors to sort and modify the information actually disseminated, the networks/social media do not have a "censor". It is possible to access information via laptops, which is an important point in places where there is no Internet connectivity. However, the use of social media by public opinion is more volatile than that of traditional media and information is more ephemeral.

\subsection{Protest and Demonstration}

Sometimes it is not enough to raise public awareness of the risks associated with 
climate change you may also need to mobilize the opinion to encourage it to act in such a way that the public authorities and other Actors become aware of the importance of the problem in the eyes of the public. The interventions that are appropriate, legal and safe will vary from one country to another, so you will have to assess the risks of adopting this or that method. Possible ideas include asking people to wear a badge or other symbol to signal their support for action on climate change; ask them to post posters at home or at work ask them to write to their elected officials or meet them to pray them to act; organize steps, gatherings, vigils and other forms of protest.

\subsection{Publicity}

Publicity has sometimes been associated with an art form, but originally advertising is simply a form of communication. It can be said that she is the individual by masking her real personal interest. It is a commercial activity that promotes a product, a service, an event, a concept, or even a person, regardless of the means used. Influenced by advertising, the consumer acts according to his immediate impulse and this impulse opposes his interests in the long term. Everything is put forward to attract attention and arouse the public's desire. Advertising can be verbal, written or visual and uses formats such as word of mouth, radio, newspapers, magazines, television, the Internet and even the walls! If you consider the modern environment, advertising is everywhere: on the road, the airports, the railway stations etc.

\section{Theoretical Value for the Study of Public Opinion}

The theoretical value of public opinion in this article is the use of the definition of public opinion which becomes more complex if one considers the different roles that it is held in modern democracies, the numerous media mirrors and Institutions that are arguing about its incarnation, its recognition, or even its rejection. Mirrors which, in fact, gradually contribute to it as a subject of self-awareness through its reflections and capable of increasingly imposing its judgments (whose strength is based on their "representativity"), The virtuous paradox of this evolution is reached when public opinion develops self-critical movements, especially after devastating rumors provoking vast ebb and flow. It is thus a real subject reflecting on its necessary flexibilities, its potential for openness and verification, while aspiring to unprecedented responsibilities of a political and even intellectual nature (inflections towards a "democratization of expertise" and enlarged citizen representativeness, development of consumerist and associative movements.

\section{Practical and Theoretical Importance of Research}

The practical importance of this research is to note that public opinion becomes crucial during periods of election campaigns. Since the last quarter of the twentieth century, it has been frequently measured using opinion polls, most often at 
the request of political parties, leaders or governments. The vast majority of these polls are never made public. There are many topics of interest to public opinion. They concern for example the economic and social situation (employment, purchasing power, pensions ...) and security (civil, food ...). Over the past few decades, the environment has been a subject increasingly addressed by the media, following the studies of scientists and the action of environmental NGOs. World public opinion has become sensitive to this theme.

On the theoretical level, public opinion, like most socio-political concepts, belongs to the category of intensionnels concepts: it does not represent a state of affairs, an empirical fact that one could, according to the criteria Strictly Nominalists of existence, touch the finger or see with one's own eyes. It has a meaning that is not determined by the vertical link between the words and the things they are meant to mean, but by the "horizontal" differentiations that are woven within the system of language conventions, Social rules and political interests that presided in its fixation. However, if it is accepted that the concept of public opinion does not belong to reality itself, but to our way of describing it, the semantic features that make up it cannot be regarded as the descriptive restitution of the substantial properties of a Physical entity.

\section{Discussion}

The term "International public opinion" is now also used by various actors outside the militant field. The media but also governments and international organizations that invoke international public opinion tend to make it a uniform and sometimes lively entity: public opinion can thus "be moved"; "indignant" and even undergo "Psychological shocks. The increasing visibility of the term "international public opinion" maintains the blurring that surrounds it.

Within the academic field, public opinion, whether national or international, remains an imprecise notion. As the note Loïc Blondiaux, (1997), the reflection around public opinion leaves (...) see this strange and often noted paradox: there is a stark contrast between the frequency of the scientific and political uses of this concept and the difficulties that the President has in its definition [15]. In international relations, international public opinion is thought to be the emanation of an international debate in gestation. It is seized through its demonstrations: for example, in 2003, converging mobilizations against the war in Iraq, the United States, Egypt, Indonesia, etc. For internationalists, the expression of international public opinion refers to the arenas of debate where more and more protesting actors meet.

The growing participation of "civilian partners" in diplomatic activities, particularly at major United Nations conferences, would testify to the existence of a world public “opinion”, Marie Claude Smouts, (1997) [16]. This phenomenon is of interest to internationalists in that it greatly affects the rules of international play. For Bertrand Badie, (2004), the emergence of international public opinion is "at the center of profound upheavals; it is a strong moment of the agony of 
power [17]. It should first be seen that individuals are in principle far removed from normative production within the framework of international law, but that despite this situation is now to be challenged with the emergence of the new notion of 'society International" [18]. Individuals above all subjects of international law, subject to it and away from its production. It must therefore be seen here that international law remains above all a distant right for individuals, subjects of it, because of the construction of very indirect representation this one, but mainly because of the fact that only states can produce of standards.

\section{Research Delimitation}

As a limitation of this research, we believe that public opinion refers to polls rather than reality. Because what is generally claimed to be measured by sampling is "public opinion". But for us, public opinion is infinitely more complex than that. Even further public opinion is not measured. Public opinion is, we think, the whole of the reflections that all citizens are doing, and that happens to a kind of common denominator, at some point every citizen shares his experiences, his observations listens to a number of comments and of people who allow it to make an opinion, and the sum of those opinions is what is, in our view, public opinion. Public opinion first it is necessary to distinguish between the two terms. "Opinion" which is a notice, a feeling, an impression ... It is not necessarily something that is palpable, that is proven. It's still ... When we say "This is my opinion and I share it" ... It's really something we believe. And "public": that is to say that it is not private ... This is something that can be used, that is known or that can be, should be. So "public opinion" is what is expressed in a poll that is well done. This is pretty rare. It is very rare in the political field. For us, public opinion is clearly the sum of the individual attitudes of each citizen, feelings that do not have to be expressed spontaneously. On the contrary, we specify that they are not naturally public, but that they are often kept for themselves ("This is my opinion and I share it"). The sum of these feelings is therefore not naturally "public", nor is it, but it can be revealed "by a well-done survey". In the absence of always having access to polls he deems valid.

\section{Conclusion}

In conclusion, as we thought, public opinion lies in attitudes rather than in political action, and refers to the mass of citizens rather than to groups or elites, a general conception expected, in the age of the survey. That said, their comments reveal more refined designs. They distinguish not only several indicators of public opinion, but several forms of public opinion, of unequal value. If a reporter can describe the occasional demonstrations of public opinion (votes, polls, declarations of interest groups, demonstrations ...), their trade requires them to go further, to interpret and anticipate the movements of public opinion. Their professional success, their contributions to the electronic media, their status as stars, and the benefits they derive from this are particularly related to this "added val- 
ue", to the ability to see not only the public as it stands, but as it will evolve. Individuals are of crucial importance to world affairs, this idea is based on certain assumptions such as, acquisitions of better analytical skills, global political system has entered a period of prolonged turbulence which makes it particularly sensitive to micropoliques influences and the upheaval of skills is considerable since citizens today shape the overall results in a much more important way than in the past.

\section{Conflicts of Interest}

The authors declare no conflicts of interest regarding the publication of this paper.

\section{References}

[1] Badie, B. (2004) The Impotence of Power. Essay on the New International Relations. Fayard, Paris, 246.

[2] Emmanuelle, C. (2006) The Apparatus of Public Opinion in the Office of Prime Minister Bernard Landry: An Analysis in the Light of the Experience of the White House. Master's Thesis, The University of Montreal, Montreal.

[3] Éthier, D. (2010) Introduction to International Relations. Presses of the University of Montréal, Montréal. https://books.openedition.org/pum/6406?lang=en

[4] Jürgen, H. (1989) The Structural Transformation of the Public Sphere: An Inquiry into a Category of Bourgeois Society. MIT Press, Cambridge.

[5] Susan, H. (1998) Reading Public Opinion: How Political Actors View the Democratic Process. The University of Chicago Press, Chicago.

[6] Susan, H. (1993) Numbered Voices: How Public Opinion Has Shaped American Politics. The University of Chicago Press, Chicago.

http://medias.dunod.com/document/9782200617080/P040-052_Comprendre-le-mo nde-Boniface.pdf

[7] Lawrence, R.J. and Robert, Y.S. (2000) Politicians Don't Pander. The University of Chicago Press, Chicago.

[8] Niklas, L. (2013) La réalité des médias de masse, trad. F. Le Bouter. Diaphanes, Bienne-Paris.

[9] Niklasm, L. (2000) Die Politik der Gesellschaft. Suhrkamp, Francfort-sur-le-Main, Suhrkamp.

[10] Luhmann (2009) Gesellschaftliche Komplexitätundöffentliche Meinung, Soziologische Aufklärung, t. 5, 4e Edition, Wiesbaden, VS Verlagfür Sozialwissenschaften, 170-182.

[11] Blondiaux, L. (1997) What Polls Do to Public Opinion. Politix, No. 37, 117.

[12] Smouts, M.C. (1997) The Equivocal Construction of a World Public Opinion. Revue Tiers Monde, 38, 677-693.

[13] Richard, N., Nevitte N., Gidengil, E. and Blais, A. (2008) Election Campaigns as Information Campaigns: Who Learns What and Does It Matter? Political Communication, 25, 229-248.

[14] Thomas, E.P. (2005) Of Polls, Mountains: U.S. Journalists and Their Use of Election Surveys. Public Opinion Quarterly, 69, 716-724. https://doi.org/10.1093/poq/nfi065

[15] François, P. (2007) How Policy Makers View Public Opinion. DansHowlett M., L. Dobuzinskyet D. Laycock, dir., Policy Analysis in Canada: The State of the Art. 
University of Toronto Press, Toronto.

[16] Rosenau, J. (1994) The Individual in International Relations. Economica, Paris, 81.

[17] Rosenstiel, T. (2005) Political Polling and the New Media Culture: A Case of More Being Less. Public Opinion Quarterly, 69, 698-715.

https://doi.org/10.1093/poq/nfi062

[18] Graham, W. (2005) Cabinets and First Ministers. UBC Press, Vancouver. 